\title{
MOBILE PHONE BRANDS PREFERENCES AMONG STUDENTS: COMPARATIVE STUDIES IN INDONESIA AND MALAYSIA
}

\author{
Silvia Dewi Sagita Andik ${ }^{* 1}$, Jono Munandar ${ }^{* *}$, Mukhamad Najib ${ }^{* *}$, and Abdul Rashid $\left.{ }^{* * *}\right)$ \\ *) College of Vocational Studies, IPB University, Indonesia \\ Jl. Kumbang, No.14 Bogor 16128, Indonesia \\ **) Department of Management, Faculty of Economics and Management, IPB University \\ Jl. Agatis, IPB Dramaga Campus, Bogor 16680, Indonesia \\ ${ }^{* * *}$ Faculty of Economics \& Management, Universiti Putra Malaysia, Malaysia \\ 43400 UPM Serdang, Selangor, Malaysia
}

\begin{abstract}
In recent years, various brands of mobile phones have dominated Indonesia and Malaysia market. Most of them are imported from other countries, such as China, America, Europe, and South Korea which are highly competitive by offering the variety of designs and functions. To compete with other competitors, Indonesian telecommunication industry needs to focus on brand management, especially in building brand preference. The aims of this research to examine factors affecting brand preference. Questionnaire surveys have been conducted to 200 respondents in Indonesia \& Malaysia. Data were analyzed by descriptive and Structural Equation Modeling Partial Least Square (SEM-PLS). SEM PLS has been conducted in order to examine the relative impact of the identified factors on brand preference. The major findings are there were differences factors affecting brand preference of mobile phone between Indonesian consumers and Malaysian consumers. Indonesian consumers are more focused on brand awareness when they have to choose mobile phone brands. On the other hands, Malaysian consumers are more focused on brand experience.
\end{abstract}

Keywords: brand awareness, brand experience, brand preference, mobile phone brand, structural equation modeling

\begin{abstract}
Abstrak: Beberapa tahun terakhir, berbagai merek ponsel telah mendominasi pasar Indonesia dan Malaysia. Sebagian besar didatangkan dari negara lain, seperti China, Amerika, Eropa, dan Korea Selatan yang memiliki daya saing tinggi dengan menawarkan desain dan fungsi yang beragam. Untuk bersaing dengan kompetitor lainnya, industri telekomunikasi Indonesia perlu fokus pada manajemen merek, terutama dalam membangun preferensi merek. Penelitian ini bertujuan untuk mengetahui faktor-faktor yang mempengaruhi preferensi merek. Survei kuesioner telah dilakukan terhadap 200 responden di Indonesia \& Malaysia. Data dianalisis secara deskriptif dan Structural Equation Modeling Partial Least Square (SEM-PLS). SEM PLS telah dilakukan untuk menguji dampak relatif dari faktor-faktor yang diidentifikasi pada preferensi merek. Temuan utama adalah terdapat perbedaan faktor yang mempengaruhi preferensi merek ponsel antara konsumen Indonesia dan konsumen Malaysia. Konsumen Indonesia lebih fokus pada brand awareness ketika harus memilih merek ponsel. Di sisi lain, konsumen Malaysia lebih fokus pada pengalaman merek.
\end{abstract}

Kata kunci: kesadaran merek, pengalaman merek, preferensi merek, merek ponsel, pemodelan persamaan struktural

\footnotetext{
${ }^{1}$ Corresponding author:

Email: silviadewi@apps.ipb.ac.id
} 


\section{INTRODUCTION}

Brand is a predictor used to establish customers' satisfaction. Brand preference is one of the strategies employed to build brand positioning (Jamal and AlMarri, 2010). For the sake of markets expansion or a new product development, industries can possibly use brand preferences as the key factor in allocating resources to develop an effective product (Jamal and Al-Marri, 2010; Alamro and Rowly, 2011).

Brand preferences are determined by several factors. In relation to this, Alamro and Rowly (2011) identify ten antecedants of brand preferences: 1) uncontrolled communication, 2) controlled communication, 3) brand personality, 4) price, 5) quality, 6) corporate status, 7) country of origin, 8) satisfaction, 9) perceived risk, and 10) reference group. Additionally, self image congruence is considered positively significant to customers' satisfaction and brand preferences (Ekinci, 2004; Jamal and Godee, 2001). In order to determine a favorable brand, consumers also consider brand experience as an antecedent of brand preference (Ebrahim et al. 2016). An attractive brand visual has good experience to consumers. In addition to brand experience, brand image also has influnce to brand preference. One of the antecedents of a brand image is the attributes of a product. It is the antecedent at which marketers need to notice (Roseli et al. 2016; Lee and Nguyen 2017). These attributes include quality, price, and country of origin. Country of origin is an important attribute to evaluate brands. Chinese and Russian consumers are generally more concerned with a brand country of origin, specifically when they purchase luxurious goods (Godey et al. 2012). Essoussi et al. (2011) also state that country of origin influences the preferences of car and television brands to Tunisian consumers. Previous studies showed that building brand preferences is essential in order to compete in a dynamic market, particularly in high involvement products category. One of the examples of such product category is mobile phone.

Indonesia and Malaysia are potential markets for mobile phones import sector. The import value of cellular phones could reach 3.158 million (Ministry of Industry, Republic of Indonesia 2016). International Data Corporation (2016) noted that 8.3 million units of mobile phones had widely spread throughout Indonesia. This number had increased by 14.4 percent since 2014. This case has also taken place in Malaysia.
International Data Corporation of Asia Pacific (2011) reported that the number of imported mobile phones had increased by 35 percent in Malaysia. The survey from the Indonesian cellular importers' association stated that during 2010, the supply of various mobile phone brands from China had reached 9.6 million units (80 percent of total imported mobile phones). A total of 200 Chinese mobile phone brands entered Indonesian market (Sumariyati, 2012). The increase in Chinese mobile phone brands indicates an increasing preference on such products. On other hand, global brands still exist in Indonesian market (International Data Corporation Asia Pacific, 2020). The information about market share of mobile phones in Indonesia provided on the Table 1.

Table 1 indicates that the market share of Chinese mobile phones has increased. Similarly, preference on Chinese mobile phones has also increased in Malaysia. Malaysian consumers' perception to Chinese mobile phones is very positive (Nadia et al. 2016).

Table 1. Market share of mobile phones in Indonesia 2020

\begin{tabular}{lc}
\hline Mobile Phone Brands & $2020(\%)$ \\
\hline Vivo (China) & 27 \\
Oppo (China) & 23 \\
Samsung (South Korea) & 19 \\
Xiaomi (China) & 14 \\
Realme (China) & 13 \\
Others & 4 \\
\hline
\end{tabular}

Source: IDC (2020)

The number of global brands in Indonesian and Malaysian markets shows that the telecommunication industry is very competitive (Alamro and Rowly, 2011). In addition, a survey conducted by Agustin et al. (2011) indicated that most youth activities in both countries took the advantage of such technology resources as mobile phones, computers, and gadgets. Hair et al. (2003) also chooses students as respondents for mobile phone brand issues as they are knowledgeable about the topic. In addition, student market is large. Then, students' consumption behaviors and perceptions resemble that of the typical users. Related to the technological advantages, Belwal and Belwal (2009) stated that students feel uncomfortable without their mobile phones so that they set it to active mode all the time. It is because they are addicted to being available online. It shows that students' consumption pattern has changed: they spend their time using their mobile phones. 
The striking difference in the two countries is demographic characteristics, namely educational, social, and cultural values. Agustin et al. (2011) reported that Malaysian society, has good education and only 2.5 percent of the society drops out of school. The education system is applied equally throughout the country. However, in Indonesia, the education system is still unevenly applied across the nation. One of the factors is its geographical condition. Based on sociocultural factors, Indonesia has a wide variety of tribes and cultures widely spread all over the region. There are more than 50 ethnic groups in Indonesia. This shows that Indonesian consumers are more heterogeneous than that of Malaysian. Differences in social and economic factors affect consumers' brand preference (Renganathan et al. 2016).

Most studies focused on single factor affecting brand preferences. Therefore, this study tried to focus on wide range of factors that affect such preferences. In addition, studies investigating mobile phones brand preferences are found to be rare. As a potential country for mobile phone products, Indonesia and Malaysia have different characteristics of socioeconomic factors. Therefore, comparative analysis between the two countries can be a new point in a study related to brand preferences. Structural Equation Modeling - Partial Least Square (SEM-PLS) was mainly used to measure a more complex research model of brand preferences. Based on the above elaboration, the problems investigated in this research are (1) what are the factors affecting on brand preference on Indonesia consumers and Malaysian consumers? (2) and whether there are differences factors affecting brand preference on both countries.

\section{METHODS}

Data were collected through a survey using questionnaire instrument. Secondary and primary data collection was carried out from April-June 2017 in Indonesia and Malaysia. Jakarta, Bogor, and Depok were chosen because that is the cosmopolitan cities in Indonesia as well as markets for International-branded goods. Similarly, Klang Valley is the center of trade and industry in Malaysia. Sampling was performed by convenience technique. This technique was chosen due to the convenience of access and willingness of respondent to be interviewed (Salkind, 2010). The total sample size was 200 (100 Indonesian students and
100 Malaysian students). The number of samples was taken based on the formula of Roscoe (1975). Roscoe (1975) states that there are several rules in determining the number of samples as follow; (1) the sample size is more than 30 and less than 500; (2) the number of samples categorized into several categories must have at least 30 samples for each category; (3) for multivariate research (including multiple regression), the sample size should be 10 times the number of latent variables in the study. There are 200 questionnaires were distributed. Descriptive analyzed were used to describe respondent characteristics. Factors affecting brand preference were analyzed with structural equation modeling technique using Smart PLS 3.0.

The theoretical model was developed based on previous research related to the antecedants of brand preference. The proposed model, with 14 constructs and 47 indicators, contributed to explaining brand preference. Table 2 summarizes the most relevant studies supporting the selection of variables and relations used in the formulation of model presented in Figure 1.

Based on the literature review related to the antecedants of brand preference, this study divided factors affecting brand preference into three group following Duarte and Raposo's (2010) study. Consumer's behavior is influenced by consumer him self, the situation, and the object. Consumer's preference towards brand is also influenced by their oriented factors, the situation, and the brand related factors.

\section{Consumers' Oriented Factors}

There are several antecedents of brand preference related to consumer's behavior, such as consumer's characteristics. Consumer's characteristics are the main interest of this study. These are the dominant influence of individual for guiding to the brand preference (Duarte and Raposo, 2010). Following the same thought, Jamal and Al-Marri (2010) found that marketers can put their brands to establish their strong brand image with consumer self-image in term of automobile product. Self-image congruence could be one of the strategies to promote products into two segments; high involvement and low involvement. Moreover, Ekinci (2004) indicates that customers use their desires as a comparison standard to assess their satisfaction. Based on the literature, we conclude that self-image congruence is one of the important factors that meets customer's satisfaction. Customer's satisfaction has 
a strong influence on brand preference (Hellier et al. 2003; Jamal 2001; Khazanizadeh and Esfidani, 2014; Wen and Hilmi, 2011). A high-level satisfaction will increase consumer's preference for the brand (Helier et al. 2003).

In addition to customer's satisfaction, brand experience also has a strong influence on brand preference (Ebrahim et al. 2016; Niedriech and Swain, 2003). Ebrahim et al. (2016) demonstrated that brand experience is related to consumer' psychology. It reflects consumers' responses to various brand stimuli and the acquired knowledge can be a source preference so that it could generate evaluations or judgments towards a brand. Brand experience is the foundation of brand preference. Other studies examine the antecedents of brand experience, such as brand personality variable and appearance (Ebrahim et al. 2016; Ramashesan and Stein, 2014). Brand personality is related to brand symbol. Ebrahim et al. (2016) imply the importance of brand experience in order to transfer the brand personality to symbolic meaning so that the brand preference can be enhanced. In addition to brand personality, appearance is also related to aesthetic design of the brand. It includes the hedonic attributes of a brand. Appearance contributes to the consumer's experimental responses.

Table 2 Studies suporting the variables and relations

\begin{tabular}{|c|c|}
\hline Path & Previous Studies \\
\hline \multirow[t]{3}{*}{ Advertising affects brand awareness } & Alamro and Rowly (2011) \\
\hline & Grace and O’cass (2005) \\
\hline & Clark et al. (2009) \\
\hline \multirow[t]{2}{*}{ Publication affects brand awareness } & Alamro and Rowly (2011) \\
\hline & Grace and O’cass (2005) \\
\hline \multirow[t]{2}{*}{ Word of Mouth affects brand awareness } & Alamro and Rowly (2011) \\
\hline & Grace and O’cass (2005) \\
\hline \multirow[t]{2}{*}{ Brand awareness affects brand preference } & Alamro and Rowly (2011) \\
\hline & Khashanizadeh and Esfidani (2014) \\
\hline Price affects brand image & Alamro and Rowly (2011) \\
\hline \multirow[t]{2}{*}{ Quality affects brand image } & Alamro and Rowly (2011) \\
\hline & Wu et al. (2011) \\
\hline \multirow[t]{4}{*}{ Country of Origin affects brand image } & Alamro and Rowly (2011) \\
\hline & Kim et al. (2015) \\
\hline & Essousi et al. (2011) \\
\hline & Lee and nguyen (2017) \\
\hline \multirow[t]{3}{*}{ Brand image affects brand preference } & Alamro and Rowly (2011) \\
\hline & Khan (2016) \\
\hline & Duarte and Raposo (2010) \\
\hline Appearance affects brand experience & Ebrahim et al. (2016) \\
\hline \multirow[t]{2}{*}{ Brand personality affects brand experience } & Ebrahim et al. (2016) \\
\hline & Ramaseshan and Stein (2014) \\
\hline \multirow[t]{2}{*}{ Brand experience affects brand preference } & Ebrahim et al. (2016) \\
\hline & Niedrich and Swain (2003) \\
\hline \multirow[t]{4}{*}{ Self image congruence affects customer satisfaction } & Ekinci (2004) \\
\hline & Jamal (2001) \\
\hline & Duarte and Raposo (2010) \\
\hline & Jamal and Al Marri (2010) \\
\hline \multirow[t]{4}{*}{ Customer satisfaction affects brand preference } & Hellier et al. (2003) \\
\hline & Jamal and Godee (2001) \\
\hline & Khashanizadeh and Esfidani (2014) \\
\hline & Wen and Hilmi (2011) \\
\hline
\end{tabular}




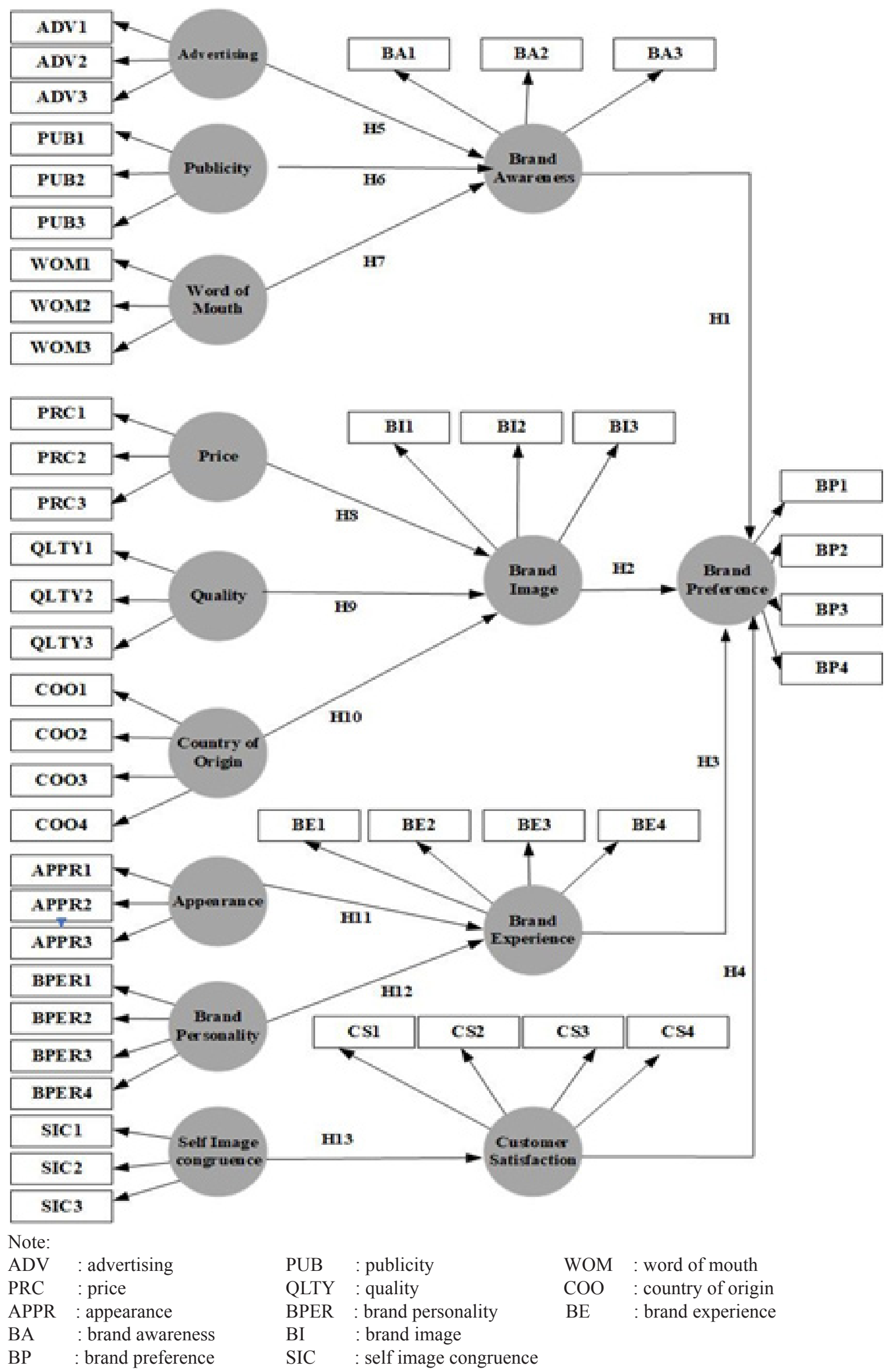

Figure 1. Initial model 


\section{Situational Factors}

Situational factors are present at precise moment and place which do not result from consumer's choice or object, but from the condition of the environtment affecting consumer's behavior (Belk, 1974). These factors include communication and social environment. Several authors stated that communication lead consumer's favor towards a brand (Duarte and Raposo, 2010; Alamro and Rowly, 2011). Alamro and Rowly (2011) divided communication into two group namely controlled communication and uncontrolloed communication. Based on Alamro and Rowly's study, advertising has an influence on consumer's awareness towards a brand. Grace and O'cass (2005) also examine the controlled communication in term of service brands. Advertising is one of the controlled communications. It also has a positif infuence on brand attitude. Communication source is used to derive brand information for consumer. Clark et al. (2009) highlight advertising as a means of providing information to consumers, it will increase their awareness of a brand. In addtiton to controlled communication, uncontrolloed communication such as publication and word of mouth have influence to brand awareness (Alamro and Rowly 2011). Grace and O'cass (2005) found that uncontrolled communication has a negative relationship. Research by Khazanizadeh and Esfidani (2014) suggested that brand awareness, advertisement, and demographic factors also had an influence on brand preference perceived quality. It has an influence on brand preference (Wang, 2013).

Brand awareness involves word of mouth, pubication, and advertisement (Alamro and Rowly, 2011). It also influencesbrandpreference(KhashanizadehandEsfidani 2014). Samsung mobile phone brand preference was examined. Consumers are attracted to Samsung's audio and visual through friends, acquintances, its website, and information collected from social networks. These factors lead consumer's favor towards to the brand. It is in line with research conducted by Alamro and Rowly (2011), they indicated that consumer's awareness has strong infuence to brand preference.

\section{Brand Related Factors}

Brand related factors include brand attributes and the product. Prior research suggest that brand image affects brand preference (Alamro and Rowly, 2011; Khan, 2016; Duarte and Raposo, 2010). Brand image is related to country of origin, price, and quality. Duarte and Raposo (2010) suggest that most consumers use brands to express their lifestyle. They prefer the brands which, in terms of the image, are closer to them. Khan (2016) stated that developing smartphone features will increase the brand preference. In addition to features, price indicates the image of the brand (Alamro and Rowly, 2011). Wu et al. (2011) also examined the influence of service quality of private brand label towards its image. It indicates that brand image plays very mportant roles. Service quaity of private brands label can enhance consumer's perception of its image. Similarly with quality of product, country of origin variable has a big effect on the brand image (Kim et al. 2015). Country of origin is one of the factors which persuades Chinese consumers in order to develop positive brand image. For them, it is important to give positive image of the brand country of origin to enhance its image

The reviews of literature, there are 13 hypotheses were developed.

\begin{tabular}{|c|c|}
\hline$\Pi$ & $\begin{array}{l}\text { brand awareness affects brand preference } \\
\text { Brand image affects brand preference }\end{array}$ \\
\hline H3 & brand experience affects brand preference \\
\hline & $\begin{array}{l}\text { customer satisfaction affects brand } \\
\text { preference }\end{array}$ \\
\hline & Advertising affects brand awareness \\
\hline & Publicity affects brand awareness \\
\hline $\mathrm{I}^{\prime}$ & Word of mouth affects brand awareness \\
\hline & Price affects brand image \\
\hline 49 & Quality affects brand image \\
\hline 10 & Country of origin affects brand image \\
\hline & Appearance affects brand experience \\
\hline & Brand personality affects brand experience \\
\hline & $\begin{array}{l}\text { Self-image congruence affects customer } \\
\text { satisfaction }\end{array}$ \\
\hline
\end{tabular}

\section{RESULTS}

\section{Respondent's Characteristics}

Table 3 shows the demographic characteristics of respondents. Based on descriptive analyses, the majority of respondents were female (59 percent for Indonesian consumers and 55 percent for Malaysian consumers). Based on age range, more than half of the total respondents ( 82 percent for Indonesian consumers and 87 percent for Malaysian consumers) were in 18-25 years old. Based on monthly expenditure, the majority 
of respondents were in the range of US\$ 67.02 to US\$ 74.47 (39 percent for Indonesian consumers and 35 percent for Malaysian consumers). Most respondents (59 percent for Indonesian consumers and 67 percent for Malaysian consumers) were at undergraduate level. Demographic characteristics have an important role for a person's brand preference. Demographic characteristics are very commonly used by marketers to determine market segmentation. The correlation between brand preference and market segmentation characteristic is an essential key for industry in order to create effective market strategy (Feng L 2007). Renganathan et al. (2016) noted that brand preference has positive significant to consumer's expanses. The difference of consumer's expenses affects consumer's brand preference.

\section{Reflective Outer Model of Indonesian and Malaysian Consumers}

On the initial model, it is carried out test criteria of outer model. Evaluation of improvement is performed on the initial model by looking at the coefficients of latent variables with the indicator. Coefficient values that are below 0.7 must be removed from the model. Evaluation of reflective outer model is performed by comparing the loading factor's value with its standard value. Elimination process of indicators that are below the standard value is done periodically.
On the final outer model of Indonesian consumers, brand awareness is reflected by two indicators, advertising is reflected by three indicators, publicity is reflected by three indicators, word of mouth is reflected by one indicator, brand image is reflected by three indicators, price is reflected by two indicators, quality is reflected by three indicators, country of origin is reflected by two indicators, brand experience is reflected by three indicators, brand personality is reflected by two indicators, the appearance is reflected by three indicators, customer satisfaction is reflected by four indicators, self-image congruence is reflected by three indicators, and brand preference is reflected by four indicators. The final outer results are shown in Figure 3. On the final outer model of Malaysian consumers, brand awareness is reflected by three indicators, advertising is reflected by three indicators, publicity is reflected by three indicators, word of mouth is reflected by three indicators, brand imae is reflected by three indicators, price is reflected by three indicators, quality is reflected by three indicators, country of origin is reflected by two indicators, brand experience is reflected by four indicators, brand personality is reflected by four indicators, the appearance reflected by three indicators, customer satisfaction is reflected by four indicators, self-image congruence is reflected by three indicators, and brand preference is reflected by four indicators.

Table 3. Description of demographic characteristics on Indonesian and Malaysian consumers

\begin{tabular}{llccc}
\hline Respondent Characteristics & Indonesia (\%) $\mathrm{n}=100$ & Malaysia (\%) $\mathrm{n}=100$ & Total (\%) \\
\hline Gender & Male & 41.0 & 45.0 & 43.0 \\
& Female & 59.0 & 55.0 & 57.0 \\
Age (years old) & $18-25$ & 82.0 & 87.0 & 84.5 \\
& $26-35$ & 12.0 & 10.0 & 11.0 \\
& $36-45$ & 6.0 & 2.0 & 4.0 \\
& $>46$ & 0 & 1.0 & 0.5 \\
Monthly Expanses & US\$ 67.02 - US\$ 74.47 & 39.0 & 35.0 & 37.0 \\
& US\$ 75.00-US\$ 89.37 & 17.0 & 15.0 & 16.0 \\
& US\$ 90.00 - US\$ 104.26 & 12.0 & 12.0 & 12.0 \\
& US\$ 105.00-US\$ 134.05 & 11.0 & 18.0 & 14.5 \\
& $>$ US\$ 135.00 & & 20.0 & 20.5 \\
Education Level & Diploma & 9.0 & 24.0 & 16.5 \\
& Bachelor degree & 59.0 & 67.0 & 63.0 \\
& Master degree & 31.0 & 5.0 & 18.0 \\
& Doctoral/PhD & 1.0 & 4.0 & 2.5 \\
\hline
\end{tabular}




\section{Outer Model Assessment of Indonesia and Malaysia}

The evaluation of the reflective outer model is conducted using four criteria. The four criteria are composite reliability $(\rho c)$, cronbach's alpha, average variance extracted (AVE), and discriminant validity of cross loading criteria. All of latent variables has composite reliability values above 0.7 (Table 4). On both models (Indonesia and Malaysia), the cronbach's alpha value for all variables is above 0.7 . Values above 0.7 indicate that internal stability and consistency of latent variable indicators are excellent. Validity is also a standard measure to shows accuracy. This measurement is described by the Average Variance Extracted (AVE) value. The AVE value for the fourteen latent variables is presented in Table 4 The standard AVE value is above 0.5 . The overall latent variables in both models (Indonesia and Malaysia) in this study had an AVE score above 0.5 . The last criterion is the discriminant validity of cross loading. The result of the cross loading criteria value indicates that both models (Indonesia and Malaysia) have correlation between indicators and latent variables.

\section{Inner Model Assessment of Indonesia and Malaysia}

Assessment of inner models is used to test the relationships among latent variables of model. There are four criteria of inner model assessment, namely $\mathrm{R}^{2}$ from endogenous latent variables, path coefficient estimation, and goodness of fit. The $\mathrm{R}^{2}$ value from the latent variables shows how large endogenous variables can be explained by exogenous variables. According to Chin (1998), the category of $\mathrm{R}^{2}$ value is divided as substantial (0.67), moderate (0.33), and weak (0.19). On the Indonesian model, the variable of brand preference that formed by exogenous variables of brand awareness, brand image, brand experience, and customer satisfaction has $\mathrm{R}^{2}$ value of 0.539 . Brand preference is explained by an exogenous variable with the variance of $53.9 \%$. While on the Malaysian model, $\mathrm{R}^{2}$ value in brand preference was at 0.415 . Based on the category of $\mathrm{R}^{2}$ values, both models belong are categorized among moderate and substantial category. On the Indonesian model, the endogenous variable of brand awareness is explained by its exogenous variables, namely advertising, publicity, and word of mouth of 0.272 . Furthermore, brand awareness is explained by its exogenous variable with the variance of $27 \%$, While on Malaysian model, $\mathrm{R}^{2}$ value of brand awareness was at 0.187 . Based on the value category, both models are in between weak and moderate categories. The endogenous variable of brand image of Indonesian model can be explained by its exogenous variables of price, quality, and country of origin with $\mathrm{R}^{\wedge} 2$ value of 0.551. Brand image variable of Indonesia may be explained by exogenous variable with the variance of $55.1 \%$. While on Malaysian model, the brand image variable can be explained by its exogenous variable of $33.4 \%$. Based on the grouping of category, the $\mathrm{R}^{\wedge} 2$ value of brand image on both models were in between moderate and substantial. On Indonesian Model, brand experience value was at 0.243. Brand experience is explained by exogenous variables, such as appearance and brand personality at $24.3 \%$. Meanwhile, brand experience of Malaysian model has a $\mathrm{R}^{2}$ value of 0.308 . Based on $\mathrm{R}^{2}$ value, both models are in the category among weak and moderate. The $\mathrm{R}^{2}$ value of the customer satisfaction variable of Indonesian model can be explained by exogenous variable (self-image congruence variable) of $17.5 \%$, while the Malaysian model is $12.6 \%$. Based on the value category, both values are in the category among weak and moderate.

Based on the bootstrap results (Table 5), there was a significant difference among Indonesian and Malaysian consumers. For Indonesian consumers, people recognition about the existence of a brand would increase the brand preference (p-value $<0.05$ ). Macdonald \& Sharp (2000) found that enhancing brand awareness is the most appropriate strategy used by marketers when consumers have no some experiences on a certain brand, then marketers have to raise consumer awareness of the brand so that the brand becomes the main preference for the consumers. In contrast on Malaysian consumers, who recognize a brand do not necessarily like the brand ( $p$-value $>0.05$ ). Brand awareness should be enhanced through effective publications in order to increase consumer preference for the brand (Nicholls \& Roslow, 2005). One of the predictors to enhancing brand awareness is advertising ( $p$-value $<0.05$ ). The more advertisement for a brand, the more people will be aware of the presence of the brand. Advertising provides important information for consumers so that it has a significant influence on brand awareness (Clark et al. 2009). But in this study, it found that publication does not affect Indonesian and Malaysian consumers in order to recognize the existence of a brand ( $\mathrm{p}$-value $>0.05$ ). Publication and word of mouth were not effective to increase brand awareness. Furthermore, the other significant 
difference between Indonesia and Malaysia consumers is a relationship brand experience to brand preference. Brand experience does not affect brand preference on Indonesian consumers ( $p$-value $>0.05$ ). In contrast for Malaysian consumers, brand experience affects brand preference ( $p$-value $<0.05$ ). it suggests that the stimulant from a good brand will provide a good experience that can increase consumer's preference for the brand. This finding is in line with the result obtained by Ebrahim et al. (2016). The difference in both countries proves that Malaysian consumers are more sensitive to the stimulant provided by a brand than Indonesian consumers.

Table 4. Reliability construct and validity of Indonesia and Malaysia model

\begin{tabular}{lcccccc}
\hline & \multicolumn{3}{c}{ Indonesia } & \multicolumn{3}{c}{ Malaysia } \\
\cline { 2 - 7 } Latent Variable & $\begin{array}{c}\text { Cronbach } \\
\text { Alpha }\end{array}$ & $\begin{array}{c}\text { Composit } \\
\text { Reliability }\end{array}$ & $\begin{array}{c}\text { Average } \\
\text { Variance } \\
\text { Extracted } \\
\text { (AVE) }\end{array}$ & $\begin{array}{c}\text { Cronbach } \\
\text { Alpha }\end{array}$ & $\begin{array}{c}\text { Composit } \\
\text { Reliability }\end{array}$ & $\begin{array}{c}\text { Average } \\
\text { Variance } \\
\text { Extracted } \\
\text { (AVE) }\end{array}$ \\
\hline advertising & 0.890 & 0.931 & 0.818 & 0.857 & 0.912 & 0.775 \\
appearance & 0.916 & 0.946 & 0.855 & 0.892 & 0.932 & 0.821 \\
brand awareness & 0.680 & 0.858 & 0.752 & 0.702 & 0.831 & 0.622 \\
brand experience & 0.773 & 0.869 & 0.688 & 0.818 & 0.877 & 0.641 \\
brand image & 0.671 & 0.820 & 0.603 & 0.800 & 0.883 & 0.716 \\
brand personality & 0.491 & 0.797 & 0.663 & 0.866 & 0.908 & 0.713 \\
brand preference & 0.941 & 0.958 & 0.850 & 0.921 & 0.944 & 0.808 \\
country of origin & 0.608 & 0.836 & 0.719 & 0.703 & 0.866 & 0.765 \\
customer satisfaction & 0.874 & 0.913 & 0.725 & 0.885 & 0.920 & 0.742 \\
Price & 0.596 & 0.831 & 0.711 & 0.798 & 0.871 & 0.694 \\
Publicity & 0.791 & 0.876 & 0.703 & 0.881 & 0.922 & 0.797 \\
Quality & 0.799 & 0.881 & 0.712 & 0.843 & 0.905 & 0.760 \\
self image congruence & 0.824 & 0.892 & 0.735 & 0.781 & 0.873 & 0.697 \\
word of mouth & 1.000 & 1.000 & 1.000 & 0.890 & 0.931 & 0.819 \\
\hline
\end{tabular}

Table 5. Bootstrap results of Indonesia and Malaysia

\begin{tabular}{|c|c|c|c|c|c|c|}
\hline & \multicolumn{3}{|c|}{ Indonesia } & \multicolumn{3}{|c|}{ Malaysia } \\
\hline & T Statistic & P Values & Hyphotheses & T Statistic & P Values & Hyphotheses \\
\hline Advertising $\rightarrow$ Brand Awareness & $4.686^{* *}$ & 0.000 & H5: Accepted & $3.397 * *$ & 0.001 & H5: Accepted \\
\hline Appearance $\rightarrow$ Brand Experience & $3.697 * *$ & 0.000 & H11: Accepted & 1.780 & 0.076 & H11: Rejected \\
\hline $\begin{array}{l}\text { Brand Awareness } \rightarrow \text { Brand } \\
\text { Preference }\end{array}$ & $2.580^{* *}$ & 0.010 & H1: Accepted & 1.179 & 0.239 & H1: Rejected \\
\hline $\begin{array}{l}\text { Brand Experience } \rightarrow \text { Brand } \\
\text { Preference }\end{array}$ & 0.368 & 0.713 & H3: Rejected & $2.047 * *$ & 0.041 & H3: Accepted \\
\hline Brand Image $\rightarrow$ Brand Preference & 1.310 & 0.191 & H2: Rejected & 0.842 & 0.400 & H2: Rejected \\
\hline $\begin{array}{l}\text { Brand Personality } \rightarrow \text { Brand } \\
\text { Experience }\end{array}$ & $2.914 * *$ & 0.004 & H12: Accepted & $4.037 * *$ & 0.000 & H12: Accepted \\
\hline Country of Origin $\rightarrow$ Brand Image & $3.679^{* *}$ & 0.000 & H10: Accepted & $2.599 * *$ & 0.010 & H10: Accepted \\
\hline $\begin{array}{l}\text { Customer Satisfaction } \rightarrow \text { Brand } \\
\text { Preference }\end{array}$ & $6.411^{* *}$ & 0.000 & H4: Accepted & $4.569^{* *}$ & 0.000 & H4: Accepted \\
\hline Price $\rightarrow$ Brand Image & 1.307 & 0.192 & H8: Rejected & 0.984 & 0.326 & H8: Rejected \\
\hline Publicity $\rightarrow$ Brand Awareness & 1.609 & 0.108 & H6: Rejected & 1.089 & 0.277 & H6: Rejected \\
\hline Quality $\rightarrow$ Brand Image & $4.849 * *$ & 0.000 & H9: Accepted & $4.539 * *$ & 0.000 & H9: Accepted \\
\hline $\begin{array}{l}\text { Self Image Congruence } \rightarrow \text { Customer } \\
\text { Satisfaction }\end{array}$ & $5.439^{* *}$ & 0.000 & H13: Accepted & $4.047^{* *}$ & 0.000 & H13: Accepted \\
\hline WOM $\rightarrow$ Brand Awareness & 0.681 & 0.496 & H7: Rejected & 0.659 & 0.510 & H7: Rejected \\
\hline
\end{tabular}


Indonesian and Malaysian consumers no longer consider brand image in evaluating brand preferences. This finding is in line with the previous report that there is a decrease in the influence of brand image on brand preference (Sakjaviee \& Samiee, 2011). Customer satisfaction had the most significant impact on brand preference ( $p$-value $<0.05)$. Both countries show that the more satisfied consumers of a brand, it will increase their preference for the brand. Improving consumer satisfaction can increase consumer loyalty to the brand (Ningsih \& Segoro, 2014).

Antecedents of brand image are price, quality, and country of origin. Quality and country of origin had an impact toward brand image. Khan (2016) emphasizes that in enhancing a brand image of smartphones, marketers have to pay attention of the brand quality as the consumers' desire. In contrast with the price factor, Indonesian and Malaysian consumers do not see the price as one of the factors that determine the image of a brand. High price levels may not necessarily reflect a good brand image. Brand personality also is one factor that may give the impression and positive experience on a brand. One example is a brand of Apple in which it impressed as elegant and exclusive. When consumers use the Apple mobile phone brand, it would be given an exclusive impression. These research also indicate that self-image congruence to be considered as part of the customer satisfaction ( $p$-value $<0.05$ ). Indonesian and Malaysian consumers evaluate a brand that suits their self-image, it will fulfill their satisfaction. This finding is in line with previous research conducted by Ebrahim et al. (2016).

The last criterion is Goodness of fit (GoF). GoF is a model goodness tested that validates the combined performance of measurement models among variables with the indicators and structural models between latent variables. GoF assessment consists of 3 categories: small (0.1), moderate (0.25), and substantial (0.36). The results of the analysis show that value of GoF at 0.549 which belongs to the substantial category. Similarly, the value of GoF at 0.451 which belongs to the substantial category. However, the Gof value of Indonesian model is larger than Malaysian model. Both models have good performance and may validate the overall model well.

Nowadays, marketers offer a variety competing for features and have their own advantages. The largest market of mobile phone brands is students. Students are a very potential market for the brand of a mobile phone. Students are a huge market, thus marketers should give attention on the student's characteristics. The level of expenditure had a positive impact on the brand preference. The marketer has to create a mobile phone product tailored to the level Consumer income. A mobile phone brand can issue various types of mobile phones in accordance with the intended target market. There are several factors affecting mobile phone brand preference for Indonesian and Malaysian consumers. Based on these results, there are different factors affecting brand preference between Indonesian and Malaysian consumers. Marketers offer mobile phones with a variety of features and their own strength. In addition to the various mobile phone attributes, there are several factors that affect the mobile phone brand preference in Indonesian and Malaysian consumers. Based on the results of this study, there are different factors affecting brand preference between Indonesian consumers and Malaysian consumers.

In Indonesian consumers, there is an influence of brand awareness and customer satisfaction on brand preference. In Malaysian consumers, there is aninfluence of brand experience and customer satisfaction on brand preference. One of antecedent customer satisfaction is self image congruence. Han et al. (2006) states that self image congruence has direct and inderect effect on brand preferences. Brand image variables do not affect brand preferences to Indonesian and Malaysian consumers. The influence of brand awareness on brand preferences shows that Indonesian consumers are more sensitive of the brand through the advertisements. Contrary to Malaysian consumers, brand awareness does not affect brand preferences.

In Malaysian consumers, brand experience has an influence on brand preference. This finding implies that Malaysian consumers are more interested in the visual impression and characteristics of brand. When consumers see an attractive visual of mobile phone brand, it will provide a good experience for the brand. Malaysian consumers prefer brand which have the same characteristics to their image. In addition, brand personality as a symbol their life style (Duarte and Raposo, 2010). Niedrich and Swain (2003) also said that the first experience of a particular brand will increase the brand's level of elegance compared to other brands. In Indonesian consumer and Malaysian consumer, there is an influence of consumers' satisfaction variable on brand preference. The more satisfied the consumers with the mobile phone brand, the more increase mobile 
phone brand preference. Brand image variables do not affect brand preference.

A complex model of brand preferences was examined using Structural equation modeling. From the analysis, there are several factors contribute to brand preferences. The strong differences on both models is that Indonesian consumers are more sensitive to advertising of the brand, while Malaysian are more sensitive to attractive characteristics of the brand. This research finding indicates that brand image does not affect brand preferences. It indicates that in complex model, factors which are individually significant can lose their power when assessed together with other factors due to the interactional effect. This view is however a starting point to know the mobile phone brand preferences among Indonesian and Malaysian consumers.

\section{Managerial Implications}

There is the differences perception of mobile phone brands between Indonesian and Malaysian consumers. There are various factors that affect brand preference. These factors are advertising, publication, brand awareness, quality, country of origin, brand personality, appearance, brand experience, customer satisfaction, and self image congruence. To win the competition in two countries (Indonesia and Malaysia), marketers should be applied the difference marketing strategy.

In Indonesia, the level of brand preference will increase if consumers become more aware of the existence of the brand. To increase brand awareness, marketers must increase the frequency of advertising. Attractive advertising will increase consumer awareness of the brand. While in Malaysia, the brand experience also influences on brand preference. Brand experience includes brand sensation, feeling, and cognition. The brand experience is also influenced by the appearance and brand personality. Brand personality is also one of the factors in providing a good brand experience for consumers. A brand must have uniqe characteristics that differentiate it between its competitors. Marketers must create unique brand characteristics in order to attract consumers. It is intended that the brand has its own characteristics. One example is to give particular characteristics to the brand.

Consumers' satisfaction will also increase brand preferences among Indonesian and Malaysian consumers. Thus, marketers should pay attention to their desires. If the consumers' desire can be fulfilled, they will feel satisfied with the brand. Marketers should pay attention to all aspects and attributes of a brand. In addition, the suitability of the brand characteristics with self-image is also very important. The suitability of self image congruence with the brand used will increase consumers' satisfaction. Hence, marketers should adjust the brand image to the intended target market. One of the examples is that students prefer design and features of the elegant brand of mobile phones. Marketers should create products that are elegantly designed

\section{CONCLUSIONS AND RECOMMENDATIONS}

\section{Conclusions}

The conclusions that can be drawn from the results and discussion of this present research is there is different perception of mobile phone brands between Indonesian and Malaysian consumers. Factors affecting brand preferences are brand awareness, brand experience, customers' satisfaction. Brand awareness is influenced by advertisment and publication. Meanwhile, brand experience is influenced by the appearance and brand personality. However, customers' satisfaction is influenced by self-mage congruence. There are different factors affecting brand preferences between Indonesia and Malaysia consumers. Indonesian consumers are more sensitive on the brand advertisement. Meanwhile, Malaysian consumers are more interested in brand personality.

\section{Recommendations}

Basedonthisresearch, thereareseveralrecommendations. In planning marketing strategy, company marketers should consider the level of consumers' preferences on the brand. They should also pay attention to the factors that affect brand preferences. One of the examples is to increase the existence of a brand by creating an engaging advertisement. In addition, marketers should also pay attention to the create attractive designs. Future research can be conducted through expanding the sample size and using such different sampling technique as random sampling. So that, the result can be used to generalize the phenomenon being researched. In addition, future research needs to select new samples, new variables as well as different products to refine the scales used to measure the constructs. This research has several limitations such as the the technique sampling, the total number of sampling and the comparison 
between 2 countries has similar characteristics. The technique sampling in this research is convenience sampling. Thus, it is not sufficiently to representative the population.

\section{REFERENCES}

Aaker D. 1991. Managing Brand Equity: Capitalizing on theValue of Brand Name. New York: The Free Press.

Acker D. 2009. Brand Equity and Advertising; Advertising's Role in Building Strong Brand. New York: Lawrence Erlbaum Associate.

Alamro A, Rowley J. 2011. Antecedents of brand preference for mobile telecommunications services. The Journal of Product and Brand Management 20(6): 475-486

Belwal R, Belwal S. 2009. Mobile phone usage behavior of university students in Oman. Infor and Servic Sci. 954-962

Brakus J, Schimch B. 2009. Brand experience; what is it?how is it measured? Journal of Marketing 73(3): 52-68

Chin WW. 1998. The Partial Least Squares Approach to Structural Equation Modeling. Modern Methods for Business Research. London: Lawrence Erlbaum Associates.

Clark C, Doraszelski U, Draganska M. 2009. The effect of advertising on brand awareness and perceived quality: An empirical investigation using panel data. Quantitative Marketing and Economics 7(2):207-236.

Dadzie A, Mensah FB. 2011. Brand preference for mobile phone operator services in the cape coast metropolis. International Journal of Business and Management 6(11): 190 - 205

Duarte PA., Raposo ML. 2010. A PLS Model to Study Brand Preference: An Application to the Mobile Phone Market. Iclemenn Handbook of Partial Least Squares. Berlin: Springer.

Ebrahim R., Ghoneim A, Irani Z, Fan Y. 2016. A brand preference and repurchase intention model: the role of consumer experience. Journal of Marketing Management. doi: 10.1080/0267257X.2016.1150322

Ekinci Y. 2004. An investigation of determinants of customer satisfaction. J Tour Analy. 8(3):197203.

Essoussi L, Merunka D, Bartikowski B. 2011. Brand origin and country of manufacture influences on brand equity and the moderating role of brand typicality. Journal of Business Research 64: 973-978.

Ferrinadewi E. 2008. Merek dan Psikologi Konsumen. Jakarta: Graha ilmu.

Godey B, Pederzoli D, Singh R, Oh H. 2012. Brand and country of origin effect on consumer decision to purchase luxury products. Journal of Business Research 65: 1461-1470.

Grace D, O'cass A. 2005. examining service experiences and post consumption evaluations. Journal of Services Marketing 18(6): 450-461

Hair J, Babin B, Money A, Samuel P. 2003.Essentials of Business Research Methods. Hoboken: Wiley Publishing.

Han JW. 2006. The Impact Of Self-Concept/ProductImage Congruity And Functional Congruity On Brand Preference: Three Product Categories. [Disertasi]. USA: Florida State University.

Hellier P, Geur G, Carr R, Rickard G. 2003. Customer repurchase intention : a general sequence model. European Journal of Marketing 37(11): 17621800.

[IDC] International Data Corporation Asia Pacific. 2020. Market Share mobile phone.. http://www. idc.com/ Asia/Pacific Quarterly Mobile Tracker 2020Q1. [20 mar 2017].

Jamal A, Al-Marri M. 2010. Exploring the effect of self-image congruence and brand preference on satisfaction : the role of expertise. Journal of marketing management 23(7-8): 613-629.

Jamal A, Goodey M. 2011. Consumers and brands ; a study of the impact of self image congruence on brand preference and satisfaction. Marketing Intelligence \& Planning 19(7): 482-492.

[KEMENPERIN] Ministry of Industry of the Republic Indonesia. 2016. import cellular phone still increase.http://www.kemenperin.go.id/ artikel/14507/Impor-Ponsel-Masih-Naik. mar 2017]

Khan M. 2016. Factors of consumer choice of smartphone : a study on brand image and brand features. Market Forces Research Journal11(2): $1-10$.

Khazanizadeh Z, Esfidani M. 2014. A survey on antecedents of brand preference (a case of samsung on audio and video product). European Online Journal of Natural and Social Sciences 3(4): 882-891.

Kim SJ, Yung KC, Kyung HK, Honglei L. 2015. Country of origin and brand image influences on 
perceptions of online game quality. Journal of Consumer Behaviour 14: 389-398

Lee J, Nguyen M. 2017. Product attribute and preference for foreign brands among vietnamese consumers. Journal of Retailing and Consumer Services 35: 76-83.

Mabkhot HA, Shaari H, Salleh SM. 2017. The influence of brand image and brand personality on brand loyalty, mediating by brand trust: empirical study. Jurnal Pengurusan 50: 71-82

Macdonald E, Sharp B. 2000. Brand awareness effects on consumer decision; making for a common. Journal of Business Research 48: 5-15.

Nadia N, Rashid W. 2016. The influence of country of origin on consumer purchase intention: the mobile phones brand from China. Procedia Economics and Finance 37: 343-349.

Nicholls J, Roslow S. 2005. Brand recall and brand preference at sponshored golf and tennis tournament. European Journal of Marketing 33(3-4): 365-386.

Niedrich R, Swain S. 2003. The influence of pioneer status and experience order on consumer brand preference. Journal of the Academy of Marketing Science 31(4): 468-480.

Ningsih S, Segoro W. 2014. The influence of customer satisfaction. switching cost and trusts in a brand on customer loyalty. Procedia Social and Behavioral Sciences 143: 1015 - 1019.

O'cass A, Lim K. 2008. The influence of brand associations on brand preference \& purchase intention. $J$ of Inter Con Market 14(2): 41-71.
Ramaseshan B, Stein A. 2014. Connecting the dots between brand experience and brand loyalty: the mediating role of brand personality and brand relationships. Journal of Brand Management 21(7/8): 664-683

Renganathan R, Anand V, Srinivasakunar V. 2016. A study on consumer brand preference with reference to dth in rural area. Indian Journal of Science and Technology 9(27): 1-5

Roscoe J. 1975. Fundamental Research Statistics for the Behavioral Sciences. New York: Holt Rinehart and Winston.

Roseli N, Azhar S, Samsudin S, Johari F, Ismail W. 2016. An analysis on the preferences of smartphone that affects consumers buying decision in selected higher education institution in Malaysia. Inter Acad Res J of Bus and Techn 2(2): 91-95.

Salkind N. 2010. Encyclopedia of Research Design. London: SAGE Publication.

Sumariyati S. 2012. Jurus Ponsel Cina Hadapi Serangan Balik Pemain Besar. http://swa.co.id/swa/ headline/jurus-ponsel-cina-hadapi-seranganbalik-pemain-besar. [20 mar 2017].

Wang E. 2013. The influence of visual packaging design on perceived food product quality. value. and brand preference. International Journal of Retail \& Distribution Management 41(10): 805816.

Wu P, Yeh G, Hsiao C. 2011. The effect of store image and service quality on brand image and purchase intention. Australasian Marketing Journal 19: 30-39. 